\title{
UPAYA GURU PENDIDIKAN KEWARGANEGARAAN DALAM PEMBENTUKAN SISWA BERKARAKTER KEBANGSAAN DI SMP NEGERI 2 BINJAI HULU TAHUN AJARAN2019/2020
}

\author{
Suparno, Lusiana \\ STKIP Persada Khatulistiwa, Program Studi Pendidikan Pancasila dan Kewarganegaraan, Sintang \\ E-mail: suparnowae4@gmail.com, Lusiana0707997@gmail.com
}

\begin{abstract}
The purpose of this study way to describe the efforts of citizenship education teacher in forming national character students through the process of learning Citizenship Educationin State Junior High Schools 2 Binjai Hulu, to describe the efforts of Citizenship Education teachers in forming students with national character through coaching outside the Citizenship Education class in State Junior High Schools 2 Binjai Hulu, to describe the supporting and inhibiting factors of the Citizenship Education teacher's efforts in the formation of students with national character class in State Junior High Schools 2 Binjai Hulu. The research method used in this research is qualitative descriptive and form of case study research. Data collection techniques use observation technique, Interview, and documentation. The results of this study indicate that: the efforts of citizenship education teacher in forming national character students through the process through intracuricular and extracurricular.
\end{abstract}

Keywords: citizenship education teacher, students, national charater 


\begin{abstract}
Abstrak
Tujuan penelitian ini untuk mendeskripsikan upaya guru PKndalam membentuk siswa berkarakter kebangsaan melalui proses pembelajaran PKn di SMP N 2 Binjai Hulu,mendeskripsikan upaya guru PKn dalam membentuk siswa berkarakter kebangsaan melalui pembinaan diluar jam pelajaran PKn di SMP N 2 Binjai Hulu, untuk mendeskripsikan faktor pendukung dan penghambat upaya guru PKn dalam pembentukan siswa berkarakter kebangsaan di SMP N 2 Binjai Hulu. Metode penelitian yang digunakan dalam penelitian ini deskriptif kualitatif dan bentuk penelitian studi kasus.Teknik pengumpulan data menggunakan teknik observasi, wawancara, dan dokumentasi. Hasil penelitian ini menunjukkan bahwa: Upayaguru PKn membentuk siswa yang berkarakter kebangsaan yaitu melalui kegiatan interakurikuler dan ekstrakurikuler.
\end{abstract}

Kata Kunci: Guru Pendidikan Kewarganegaraan, Siswa, Karakter Kebangsaan 


\section{A. Pendahuluan}

Pendidikan adalah suatu usaha sadar yang dilakukan secara sistemastis untuk mewujudkan suasana belajar-mengajar agar peserta didik memperoleh pembelajaran pengetahuan, keterampilan serta tempat peserta didik menempa sikap dan kepribadian. Sesuai dengan amanat Undang-Undang (UU) Nomor 20 Tahun 2003 tentang sistem pendidikan nasional yang berbunyi :

"Pendidikan adalah usaha sadar dan terencana untuk mewujudkan suasana belajar dan proses pembelajaran agar peserta didik secara aktif mengembangkan potensi dirinya untuk memiliki kekuatan spiritual keagamaan, pengendalian diri, kepribadian, kecerdasaan, akhlak mulia, serta keterampilan yang diperlukan dirinya, masyarakat, bangsa dan negara'.

Selaras dengan amanat Undangundang tentang sistem pendidikan nasional pendidikan merupakan usaha sadar dan merupakan program yang sudah terencana agar peserta didik dapat mengembangkan potensi dirinya dengan baik.Dalam dunia pendidikan diperlukannya seorang guru.Guru adalah orang dewasa yang bertanggung jawab dalam mendidik, mengajar, dan membimbing peserta didik (Uno, 2014: 15).

Profesi sebagai seorang guru jika tugasnya hanya mengajar atau memberikan ilmu pengetahuan serta wawasan itu sangat mudah namun ada tugas guru yang sangat berat yaitu mendidik peserta didiknya untuk berahlak mulia yang bertingkah laku berlandaskan Pancasila. Merujuk pada hal tersebut, inti utama tugas seorang guru adalah mendidik

Upaya guru dalam rangka mencerdaskan kehidupan bangsa dan meningkatkan kualitas peserta didik, perlu kerja sama antara pihak sekolah dan dewan guru yang ada disekolahan tersebut. Upaya membentuk karakter kebangsaan diperlukan guru PKn sebagai pemegang amanah dan tanggungjawab yang penuh agar peserta didik memiliki karakter yang kuat sebagai generasi penerus bangsa ISSN: $2540-8038$ 
yang siap untuk menghadapi perkembangan zaman yang makin maju dan modern.

Sekolah merupakan tempat siswa menempuh pendidikan secara formal. Dunia pendidikan dan pengajaran yang menjadi utama fokus penelitian adalah peserta didik, baik di taman Kanak-kanak, Sekolah Dasar, Pendidikan Menengah atau pun di Perguruan Tinggi. Selain fokus pada kecerdasan akademiknya seorang guru juga harus lebih memperhatikan karakter dari anak tersebut. Memang hal tersebut salah satu tujuan yang diperoleh dari kita menuntut ilmu akan tetapi semua itu tidak akan ada artinya jika kita tidak memiliki karakter yang baik, karakter yang berkualitas yang berlandaskan jiwa Pancasila.

Karakter merupakan ciri khas yang dimiliki oleh seseorang.Setiap orang memiliki karakter yang berbeda-beda.Menurut Salahudin dan Alkrienciehie (2013: 42) karakter adalah nilai-nilai yang khas baik (tahu nilai kebaikan, mau berbuat baik, nyata berkehidupan baik, dan berdampak baik terhadap lingkungan) yang terpatri dalam diri dan terwujud dalam perilaku.Dalam hal ini guru PKn harus bisa menanamkan nilai-nilai karakter kebangsaan pada peserta didik. Senada dengan pendapat diatas menurut Kementerian Pendidikan Nasional nilai karakter bangsa yang perlu diterapkan pada peserta didik yaitu religius, jujur, toleransi, displin, kerja keras, kreatif, mandiri, demokrasi, rasa ingin tahu, semangat kebangsaan, cinta tanah air, menghargai prestasi, bersahabat, cinta damai, gemar membaca, peduli lingkungan, peduli sosial dan bertanggungjawab.

\section{B. Metode}

Menurut Sugiyono (2013: 2) metode penelitian pada dasarnya merupakan cara ilmiah untuk mendapatkan data dengan tujuan dan kegunaan tertentu. Metode yang digunakan dalam penelitian ini adalah metode penelitian kualitatif deskriptif.Afrizal (2015: 13) metode penelitian kualitatif didefinisikan sebagai metode penelitian ilmu-ilmu sosial yang mengumpulkan dan 
menganalisis data berupa kata-kata (lisan maupun tulisan) dan perbuatan-perbuatan manusia serta peneliti tidak berusaha menghitung atau mengkualifikasikan data kualitatif yang diperoleh dan dengan demikian tidak menganalisis angkaangka.Bentuk penelitian ini adalah studi kasus. Menurut Mulyana (2013: 201) studi kasus adalah uraian dan penjelasan komperehensif mengenai berbagai aspek seorang individu, sutau kelompok, suatu organisasi, suatu program atau situasi sosial.Penelitian ini dilaksanakan di SMP Negeri 2 Binjai Hulu di Desa Telaga II, Kecamatan Binjai Hulu Kabupaten Sintang.Adapun teknik pengumpulan data yang digunakan dalam penelitian ini yaitu teknik observasi langsung, wawancara, dan dokumentasi.Alat yang digunakan untuk mengumpulkan data yaitu panduan observasi, paduan wawancara, dan dokumentasi.Dalam penelitian ini peneliti menggunakan model analisis data Model Miles and Huberman.

\section{Pembahasan Dan Hasil}

Upaya yang dilakukan guru PKn dalam membentuk siswa berkarakter kebangsaan berdasarkan wawancara yang dilakukan peneliti di lapangan bahwa upaya yang dilakukan seorang guru melalui pembelajaran PKn yang meliput :

a. Nilai-nilai karakterdalam setiap materi pembelajaran di kelas sesuai yang direncanakan atau sesuai RPP.

b. Menanamkan nilai-nilai karakter pada kegiatan pembelajaran di kelas melalui diskusi kelompok.

c. Menanamkan nilai-nilai karakter dalam kegiatan-kegiatan pembiasaan (upacara hari senin maupun hari besar lainnya, piket umum, piket kelas, operasi semut, dan menyanyikan lagu kebangsaan sebelum masuk pelajaran.

d. Menanamkan nilai-nilai karakter dalam kegiatan-kegiatan peringatan hari besar nasional.

Sedangkan upaya yang dilakukan guru Pendidikan Kewarganegraan dalam membentuk siswa berkarakter kebangsaan 
melalui pembinaan diluar jam pelajaran PKn yaitu melalui :

a. Ekstrakurikuler Pramuka

1. Upaya guru Pendidikan Kewarganegaraan dalam pembentukan siswa berkarakter kebangsaan melalui proses pembelajaran PKn di SMP Negeri 2 Binjai

\section{Hulu}

Upaya yang dilakukan guru PKn dalam membentuk siswa berkarakter kebangsaan melalui proses pembelajaran PKn meliputi :

a. Memasukkan nilai-nilai karakter dalam setiap materi pembelajaran di kelas sesuai yang direncanakan atau sesuai RPP.

b. Menanamkan nilai-nilai karakter pada kegiatan pembelajaran di kelas melalui diskusi kelompok.

c. Menanamkan nilai-nilai karakter dalam kegiatan-kegiatan pembiasaan (upacara hari senin maupun hari besar lainnya, piket umum, piket kelas, operasisemut, dan menyanyikan lagu kebangsaan sebelum masuk pelajaran).

d. Menanamkan nilai-nilai karakter dalam kegiatan-kegiatan peringatan hari besar nasional (PHBI).

e. Memberikan penilaian pendidikan karakter melalui penilaiaan sikap dan perilaku, Secara rinci hal yang dilakukan guru PKn di SMP Negeri 2 Binjai Hulu pada saat proses pembelajaran berlangsung yaitu:

a) Mengupayakan setiap memulai dan mengakhri pelajaran untuk mengajarkan peserta didik untuk berdo'a, hal ini tentunya demi mewujudkan nilai pancasila yang Pertama yaitu Ketuhanan Yang Maha Esa. Karena sebagai makhluk yang beriman kita harus bisa menjalankan agama menurut kepercayaan kita masing-masing.

b) Melatih mereka untuk tidak membuka catatan pada saat ada ujian atau tes, hal ini untuk melatih kejujuran siswa-siswi, hal ini tentunya untuk 
mewujudkan nilai pancasila yang kelima.

c) Melatih mereka untuk membiasakan diri hadir tepat waktu pada sebelum jam pelajaran dimulai, kemudian membiasakan diri untuk mematuhi aturan yang berlaku, serta menggunakan pakaian yang sudah ditentukan hal ini untuk mewujudkan karakter displin pada siswa. Hal ini tentunya untuk mewujudkan pancasila yang keempat.

d) Mengupayakan mereka untuk bersungguh-sungguh dalam

e) mengerjakan tugas, hal ini merupakan untuk melatih mereka untuk selalu bekerja keras. Hal ini tentunya untuk mewujudkan pancasila yang kelima.

f) Mengupayakan mereka untuk bertanggung jawab dengan mengumpulkan tugas yang sudah diberikan dalam waktu yang sudah ditentukan, hal ini untuk mewujudkan pancasila yang keempat. g) Mengupayakan mereka untuk bisa menciprtakan sesuatu terutama dalam menciptakan situasi belajar yang bisa menumbuhkan daya pikir dan bertindak kreatif. Hal ini untuk mewujudkan pancasila yang ketiga.

h) Mengupayakan mereka untuk saling menghormati orang yang lebih tua dan lebih muda, contohnya menghormati guru yang sedang menjelaskan didepan. Hal ini untuk mewujudkan pancasila yang kedua dan kelima.

i) Mengupayakan mereka untuk mengharga perbedaan yang ada disekolahan baik itu agama, suku, pendapat dan lain sebagainya. Hal ini untuk mewujudkan pancasila yang kedua yaitu kemanusiaan yang adil dan beradab, karena nilainilai yang terjabar didalam pancasila yang kedua yaitu mengakui persamaan hak tanpa membeda-bedakan suku, agama, etnis, pendapat dan lain sebagainya.

ISSN: $2540-8038$ 
j) Melatih mereka untuk belajar mandiri dalam mengerjakan tugas tanpa harus melihat hasil pekerjaan teman yang lainnya. Tentunya juga ini melatih kejujuran mereka. Hal ini untuk mewujudkan pancasila yang kelima.

k) Selalu mengajarkan kepada mereka untuk berdemokrasi sebagai negara indonesia harus bisa menerapkan itu dan memulainya harus dari lingkungan sekolah, contoh kecilnya yaitu harus mengambil keputusan melalui musyawarah bersama Hal ini untuk mewujudkan pancasila yang ke empat yaitu kerakyatan yang dipimpin oleh hikmah kebijaksanaan dalam permusyawaatan/perwakilan.

1) Selalu memberikan kesempatan mereka untuk bertanya akan hal-hal yang belum dipahami. Hal ini untuk menguji letak rasa ingin tahu siswa-siswi. Hal ini untuk mewujudkan pancasila yang ketiga. m) Selalu mewajibkan mereka untuk mengikuti upacara pada hari senin dan hari-hari besar lainnya. Hal ini untuk mewujudkan pancasila yang ketiga.

n) Selalu mewajibkan mereka untuk menggunakan bahasa indonesia pada saat dilingkungan sekolah terutama terhadap teman yang berbeda suku. Hal ini untuk mewujudkan pancasila yang ketiga yaitu persatuan indonesia. Artinya kita harus dengan bangganya mengembangkan budayabudaya yang ada di indonesia.

o) Selalu mengajrakan mereka untuk mempertahkan prestasi yang sudah didapat serta mengembangkannya. Hal ini untuk mewujudkan pancasila yang kelima yaitu keadilan sosial yang adil dan beradab. Artinya kita harus bekerja keras serta menghargai hasil karya orang lain yang bisa memberikan mamfaat bagi kita.

ISSN: 2540 - 8038 
p) Selalu mengajarkan kepada

Selain

itu

menurut mereka untuk berkomunikasi Sayektiningsih

(2017: dengan baik dengan bahasa yang santun. Hal ini untuk mewujudkan pancasila yang kedua.

Pendidikan karakter pada berbagai mata pelajaran dilaksanakan dengan mengintegrasikan pendidikan karakter dalam pembelajaran

q) Selalu mengajarkan mereka untuk menciptakan suasana kelas yang damai, akur terhadap yang lain. Hal ini untuk mewujudkan pancasila yang ketiga.

r) Selalu mengajarkan mereka untuk mengunjungi perpustakaan tentu nya untuk mengembangkan budaya membaca siswa-siswi. Hal ini untuk mewujudkan pancasila yang kedua.

s) Selalu mengupayakan mereka untuk menjaga lingkungan serta peduli terhadap sesama. Hal ini untuk mewujudkan pancasila yang kedua.

Hal ini di dukung oleh pernyataan Moclas Samani dan Hariyanto (2011: 22) setiap aspek karakter harus dijiwai oleh kelima sila Pancasila secara utuh dan komprehensif. berbasis standar.

2. Upaya guru Pendidikan Kewarganegaraan dalam pembentukan siswa berkarakter kebangsaan melalui pembinaan diluar jam pelajaran PKn di SMP Negeri 2 Binjai Hulu

Upaya yang dilakukan guru PKn tidak hanya melalui pembelajaran namun melalui pembinaan diluar jam pelajaran. Upaya yang dilakukan seorang guru dalam membentuk siswa berkarakter kebangsaan pada saat diluar jam pelajaran yaitu dengan mewajibkan siswa-siswi untuk mengikuti ektrakurikuler seperti pramuka yang dilaksanakan pada juma't sore, didalam kegiatan pramuka nilai-nilai kepramukaan adalah nilai-nilai positif yang diajarkan dan ditanamkan kepada para anggota Pramuka.Nilai-nilai kepramukaan 
bersumber dari Dasa Dharma pramuka yang berbunyi :

a) Takwa kepada Tuhan Yang Maha Esa, nilai yang terdapat pada dasa darma yang pertama ini adalah siswa harus memiliki sifat takwa kepada Tuhan yang Esa, senantiasa harus selalu mensyukuri apa yang diberi oleh Tuhan, beribadah menurut agama dan kepercayaan masingmasing serta menghormati kepercayaan orang lain. Dasa darma pertama ini tentunya untuk mewujudkan nilai karakter religius.

b) Cinta alam dan kasih sayang sesama manusia, nilai yang terdapat pada dasa darma yang kedua ini yaitu siswa selalu dituntut untuk mencintai alam, menjaga lingkungan, serta menyayangi sesama dan menolong teman yang susah demi memupuk rasa solidaritas dan kekeluargaan. Nilai karakter yang terkandung dalam dasa darma yaitu peduli lingkungan dan peduli sosial, bersahabat dan komunikatif.

c) Patriot yang sopan dan kesatria, nilai yang terdapat pada dasa darma yang ketiga ini yaitu siswa harus memiliki sifat patriot dalam membela

kebenaran. Memiliki sifat sopan terhadap sesama serta memiliki sifat kesatria dalam membela bangsa dan tanah air. Nilai karakter yang terkandung dalam dasa darma yaitu semangat kebangsaan dan cinta tanah air.

d) Patuh dan suka bermusyawarah, nilai yang terdapat pada dasa darma yang ke empat yaitu siswa dituntut untuk senantiasa selalu mematuhi hukum dan peraturan yang ada. Mereka juga dituntut untuk selalu bermusyawarah dalam mengambil keputusan serta mendengarkan pendapat dan masukan satu sama lain. Hal ini tentunya untuk mewujudkan nilai karakter kedisplinan, toleransi dan demokrasi.

e) Rela menolong dan tabah, nilai yang terdapat pada dasa darma yang kelima yaitu siswa harus saling menolong dan membantu orang yang kesusahan. Mereka harus membantu dengan tanpa pamrih, dan selalu tabah dalam menghadapi segala cobaan dan ujian dengan terus bersemangat. Nilai karakter yang terkandung dalam dasa darma yaitu peduli lingkungan sosial. 
f) Rajin, trampil dan gembira, nilai yang terdapat pada dasa darma yang keenam yaitu siswa harus memiliki sifat rajin dalam mengerjakan hal apapun dan menjauhi sifat malas. Harus trampil dalam mengeluarkan bakat yang dimilikinya, serta selalu gembira dalam segala usaha yang telah dikerjakan. Nilai karakter yang terkandung dalam dasa darma yaitu mengargai prestasi, gemar membaca, kerja keras dan kreatif.

g) Hemat, cermat dan bersahaja, nilai yang terdapat pada dasa darma yang ketujuh yaitu melalui pramuka siswa diajarkan untuk hidup hemat. Mereka harus cermat dalam memperhitungkan sesuatu dan harus menjad pribadi yang bersahaja disetiap waktu. Nilai karakter yang terkandung dalam dasa darma yaitu mandiri dan rasa ingin tahu.

h) Displin, berani dan setia, nilai yang terdapat pada dasa darma yang kedelapan yaitu melalui pramuka siswa harus displin dalam hal apapun terutama waktu. Mereka harus memiliki sikap berani terhapa hal apapun yang dihadapinya. Mereka juga harus memiliki sikap setia kepada bangsa dan negara. Nilai karakter yang terkandung dalam dasa darma yang kedelapan yaitu kedisplinan dan cinta tanah air

i) Bertanggung jawab dan dapat dipercaya, nilai yang terdapat pada dasa darma yang kesembilan yaitu melalui pramuka siswa diajarkan untuk menjadi orang yang bertanggung jawab dan juga harus dapat dipercaya dalam mengemban tugas yang diberikan dengan menjalankan tugas itu sebaikbaiknya. Nilai karakter yang terkandung dalam dasa darma kesembilan yaitu tanggung jawab dan kejujuran.

j) Suci dalam pikiran, perkataan dan perbuatan, nilai yang terdapat pada dasa darma yang kesepuluh yaitu melalui pramuka siswa dalam berfikir, berkata dan berbuat harus di jalan yang benar. Mengambil segala sesuatu dari hal positifnya serta mengambil hikmah disetiap kejadian sebagai bahan pelajaran hidup kedepannya. Nilai karakter yang terkandung dalam dasa darma kesepuluh yaitu kejujuran. 
Kegiatan ekstrakurikuler merupakan bagian dari pendidikan non formal yang biasanya dilakukan pada sore hari contohnya yaitu ekstrakurikuler pramuka. Menurut Supardi dkk (376: 2014) kegiatan ekstrakurikuler dilaksanakan dalam rangka pengembangan kepribadian, bakat, dan kemampuan lain di luar akademik dengan tujuan memberikan manfaat positif kepada peserta didik. Kegiatan esktrakurikuler merupakan kegiatan yang dilaksanakan secara terorganisir oleh peserta didik baik di tingkat sekolah maupun perguruan tinggi di luar jam belajar kurikulum standar. Di SMP N 2 Binjai Hulu apabila peserta didik melanggar atau tidak mengikuti kegiatan-kegiatan yang sudah diprogramkan dari sekolah maka peserta didik akan mendapatkan sanksi yaitu berupa mengumpulkan batako untuk 1 kali pertemuan memberikan 2 batako.

\section{Faktor pendukung dan} penghambat upaya guru Pendidikan Kewarganegaraan dalam pembentukan karakter kebangsaan di SMP Negeri 2 Binjai Hulu a. Faktor Pendukung

Sebagai seorang guru dalam membentuk karakter siswa itu ada faktor pendukung dan faktor penghambatnya.Berdasarkan penelitian dilapangan bahwa faktor pendukung dalam membentuk karakter siswa yaitu antara lain:

1) Untuk mewujudkan visimisi sekolah.

2) Untuk mewujudkan program $7 \mathrm{~K}$ yang ada disekolah tersebut.

3) Karena kebijakan dari Kepala Sekolah.

Hal tersebut didukung dengan pernyataan Yudianti (2018: 57) visi dan misi merupakan elemen yang sangat penting dalam sekolah, dimana visi dan misi digunakan agar dalam operasionalnya bergerak pada track yang diamanatkan oleh para stakeholder dan berharap mencapai kondisi yang diinginkan dimasa yang akan datang. Selain itu menurut Taufan (2015: 67) Kebijakan ISSN: $2540-8038$ 
dari kepala sekolah adalah kepala sekolah meminta koordinator pendidikan inklusif untuk membantu dan menseleksi siswa-siswa baru, memberi kebijakan kepada semua guru untuk bebas mengatur kondisi ruang kelasnya. Berdasarkan penelitian yang ditemukan peneliti di SMP N 2 Binjai Hulu kepala sekolah memberikan kebijakan bahwa memberikan kebebasan kepada semua guru untuk memanajemen baik pada proses pembelajaran maupun diluar pembelajaran.

b. Faktor penghambat

Dalam proses membentuk
karakter peserta didik tidak
selalu berjalan dengan baik,
selalu adanya kendala-kendala
atau faktor yang menghambat
jalannya seorang guru dalam
membentuk karakter peserta
didik. Berdasarkan hasil
penelitian yang telah dilakukan
peneliti menemukan beberapa
faktor penghambatnya yaitu:
1. Sarana dan prasarana sekolah
yang masih kurang

2. Minimnya waktu bertemu dengan peserta didik.

Kedua faktor diatas menjadi faktor penghambat seorang guru PKn dalam membentuk siswa barkarakter kebangsaan di SMP Negeri 2 Binjai Hulu. Dengan keterbatasan sarana dan prasarana akan susah seorang guru untuk menerapkan kedelapan belas nilai karakater kepada peserta didik.

\section{Simpulan}

Berdasarkan hasil penelitian dan pembahasan yang telah dikemukakan oleh peneliti yang bersumber dari hasil observasi, wawancara dan penelitian mengenai upaya guru Pendidikan Kewarganegaraan dalam pembentukan siswa berkarakter kebangsaan di SMP Negeri 2 Binjai Hulu tahun ajaran2018/2019, maka dapat disimpulkan sebagai berikut:

1. Upaya guru Pendidikan Kewarganegaraan dalam membentuk siswa berkarakter kebangsaan melalui proses pembelajaran PKn di SMP ISSN: 2540 - 8038 
Negeri 2 Binjai Hulu yaitu melalui kegiatan intrakurikuler yang meliputi memasukkan nilai-nilai karakter dalam setiap materi pembelajaran di kelas sesuai yang direncanakan atau sesuai RPP ,menanamkan nilainilai karakter pada kegiatan pembelajaran di kelas melalui diskusi kelompok, menanamkan nilai-nilai karakter dalam kegiatan-kegiatan pembiasaan (upacara hari senin maupun hari besar lainnya, piket umum, piket kelas, operasi semut, dan menyanyikan lagu kebangsaan sebelum masuk pelajaran), dan menanamkan nilai-nilai karakter dalam kegiatan-kegiatan peringatan hari besar nasional.

2. Upayaguru Pendidikan Kewarganegaraan dalam membentuk siswa berkarakter kebangsaan melalui pembinaan diluar jam pelajaran $\mathrm{PKn}$ di SMP Negeri 2 Binjai Hulu yaitu dengan mewajibkan peserta didik untuk mengikuti ekstrakurikuler yang biasanya di programkan oleh sekolah pada sore hari yaitu kegiatan pramuka.

3. Faktor pendukung dan penghambat upaya guru Pendidikan Kewarganegaraan dalam pembentukan siswa berkarakter kebangsaan di SMP Negeri 2 Binjai Hulu, adapun faktor pendukungnya yaitu untuk mewujudkan visi-misi sekolah, untuk mewujudkan program $7 \mathrm{~K}$, serta karena adanya kebijakan kepala sekolah. Sedangkan faktor penghambatnya yaitu sarana dan prasarana yang kurang memadai disekolah tersebut sehingga ketidakefektivan guru dalam melaksanakan semua kegiatan yang berkaitan dengan proses pembentukan karakter siswa, kemudian terbatasnya waktu guru untuk bertemu dengan siswa.

\section{Daftar Rujukan}

Afrizal. 2013. Metode Penelitian Kualitatif.Jakarta: PT. Raja Grafindo Persada.

Alkrienciehie, DKk. 2013. Pendidikan karakter Pendidikan berbasis ISSN: 2540 - 8038 
agama \& budaya bangsa. Bandung: Cv Pustaka Setia.

B. Uno, H. H. 2014. Profesi

Kependidikan. Jakarta: Bumi Aksara.

Mulyana, Dedy. 2013. Metode Penelitian Kualitatif. Bandung: PT Remaja Rosdakarya offset.

Samani , Dkk. 2016. Konsep dan Model Pendidikan Karakter. Bandung: PT Remaja Rosdakarya.

Sayektiningsih, dkk. 2017. Penanaman Nilai-Nilai Karakter Dalam Pembelajaran Pendidikan Pancasila Dan

Kewarganegaraan Di Madrasah Aliyah Muhammadiyah Klaten. Jurnal Managemen Pendidikan.Vol. 12, No. 2, Juli 2017: 228-238.

Sugiyono. 2013. Metode Penelitian Kuantitatif Kualitatif dan $R \& D$. Bandung: Alfabeta.

Taufan, Dkk. 2015.Kebijakankebijakan Kepala Sekolah dalam Penyelenggara pendidikan Inklusif di Sekolah X di Kota Jambi.Jurnal Kebijakan sekolah.Vol.1, No.4, Juli 2016.

Yudianti, A. L .2018. Implementasi Visi dan Misi Sekolah dalam membina karakter religius
siswa.Tesis.Yogyakarta : Fakultas Pendidikan Agama Islam Universitas UIN Sunan Kalijaga. 